\title{
Workshop Tari Anak di SD Negeri Sudimoro 01 Kecamatan Bululawang Kabupaten Malang
}

\author{
Ratih Kartika Werdiningtiyas ${ }^{1}$, Denna Delawanti Chrisyarani ${ }^{2}$ \\ ${ }^{\mathbf{1}}$ Fakultas Ilmu Pendidikan, Universitas Kanjuruhan Malang \\ Email: Ratihkartika26@Gmail.Com¹; dennadelawanti@unikama.ac.id².
}

\begin{abstract}
ABSTRAK
SDN Sudimoro 1 Kecamatan Bululawang belum dilakukan kegiatan ekstrakurikuler seni tari, dari beberapa wali murid berinisiatif mengikutkan anaknya untuk mengikuti les seni tari di sanggar tari daerah sekitar. Pada saat akan diadakannya pentas seni, pihak sekolah kesulitan mencari pelatih seni tari karena minimnya pelatih, lokasi yang terlalu jauh dari warga dan kurangnya materi tentang tari anak. Berdasarkan kondisi di SDN Sudimoro 1 maka sangat pentingnya diadakan tentang pelatihan tari untuk anak sekolah dasar, khususnya kelas rendah.. Kegiatan pengabdian ini dilaksanakan lima hari, hari pertama penyampaian materi gerak dasar tari semut, hari kedua sampai kelima peserta melakukan praktik ragam gerak tari semut berserta pola lantainya. Kegiatan workshop bertujuan dapat meningkatkan kemampuan siswa dalam memaksimalkan penggunaan tari semut sebagai pembelajaran yang sesuai dalam pembelajaran seni tari, mengembangkan dan menciptakan materi pembelajaran seni budaya khususnya seni tari terkait dengan konsep, dan meningkatkan kemampuan sekaligus skill siswa.
\end{abstract}

Kata kunci: Tari kreasi anak, Tari semut, SDN Sudimoro 1

\section{ABSTRACT}

SDN Sudimoro 1 Bululawang subdistrict has not done extracurricular activities of dance art, from some guardians initiative to involve his children to follow the dance and dance arts in the local dance studio. At the time of art performances, the school finds it difficult to find a dance coach because of the lack of coaches, locations that are too far from the citizens and lack of material about children's dance. Based on the condition of SDN Sudimoro 1, it is very important to be held about dance training for elementary school students, especially low grade. This devotional activity is held five days, the first day of delivery of basic ant dance material, second day until the five participants perform the practice of motion variety of ant dance along with the floor pattern. The purpose of the workshop is to improve students' ability in maximizing the use of ant dance as a suitable learning in dance, developing and creating cultural art learning materials, especially dance art related to the concept, and improving students ability and skill.

Keywords: Dance of children creations, Ant dance, SDN Sudimoro 1

\section{PENDAHULUAN}

Pendidikan sangat berperan penting dalam meningkatkan perkembangan suatu bangsa. Meningkatkan kualitas pendidikan adalah tanggungjawab semua pihak yang terlibat dalam pendidikan terutama guru. Pembelajaran di SD adalah proses dimana siswa menggali kemampuan dasar sejak dini. Seni budaya dan keterampilan merupakan salah satu bidang studi yang 
menduduki peranan penting dalam pendidikan. Pelajaran seni budaya dan keterampilan dalam pelaksanaan pendidikan diberikan kepada semua jenjang pendidikan. Pada kurikulum SD diketahui bahwa pembelajaran seni budaya membangun kemampuan dasar yang kokoh tentang pemahaman konsep, ide-ide, gagasan, bakat dan minat (Depdiknas, 2007). Diharapkan dengan belajar seni budaya siswa memiliki sikap disiplin, ulet, dan percaya diri.

Pada kurikulum terdapat pembelajaran intrakurikuler yang pembelajarannya masuk dalam jam wajib belajar, dan ektrakurikuler yang pembelajarannya di luar jam wajib matapelajaran. Sekolah merupakan lembaga pendidikan, yang menampung peserta didik yang dibina agar mereka memiliki kemampuan, bakat dan minat, kecerdasan dan keterampilan. Menurut Lutan (1986: 10.45) salah satu wadah pembinaan siswa di sekolah adalah kegiatan ekstrakurikuler.

Dari hasil observasi, di SD Sudimoro 1 kecamatan Bululawang belum dilakukannya kegiatan ekstrakurikuler seni tari, dari beberapa walimurid berinisiatif mengikutkan anaknya untuk mengikuti les seni tari di sanggar tari daerah sekitar. Berdasarkan kondisi di SDN Sudimoro 1 maka sangat pentingnya diadakan tentang pelatihan tari untuk anak sekolah dasar, khususnya kelas rendah.
Dengan pemberian pelatihan atau workshop, diharapkan siswa dapat meningkatkan kemampuan dalam karya seni tari dan dapat meningkatkan pembelajaran seni tari baik intra maupun ekstrakurikuler di sekolah.

Ekstrakurikuler seni tari sangat berguna sebagai pengembang bakat dan minat anak. Sama halnya yang diungkapkan Rohidi (dalam Hidajat, 2008: 4) tujuan pendidikan seni yaitu (1) sebuah strategi atau cara memupuk, mengembangkan sensivitas dan kreatifitas, (2) memberi peluang seluas-luasnya kepada siswa untuk berekspresi, dan (3) mengembangkan pribadi anak kearah pembentukan pribadi yang utuh maupun menyeluruh, baik secara individual, sosial maupun budaya. Berdasarkan uraian di atas seni tari berfungsi sebagai media bahkan sarana pendidikan dan pendidikan terapi, jadi tidak hanya berfungsi sebagai sarana upacara, hiburan, atau pertunjukkan saja. Seni tari di SD selain sebagai pengembang kreatifitas, bakat, dan minat anak.

\section{METODE PENELITIAN}

Untuk mewujudkan hasil yang diharapkan, beberapa kegiatan yang akan dilakukan adalah: Mengadakan konsultasi dengan Kepala Sekolah SDN Sudimoro 1, meminta izin pelaksanaan pelatihan, mempersiapkan materi kegiatan, setelah persiapan selesai, ditetapkan waktu kegiatan 5 hari yaitu hari senin sampai hari jumat tanggal 8-12 Mei 
2017 pukul 12.30-15.00 di SDN Sudimoro 2.

\section{HASIL DAN PEMBAHASAN}

Pelaksanaan

program

pengabdian ini dilaksanakan lima hari dibagi dalam lima sesi dengan rincian materi pada tiap pertemuan/sesi sebagai berikut:

Sesi Pertama, hari senin tanggal 8 Mei 2017 pukul 12.3015.00 dimulai dengan pembukaan dan sambutan. Penyampaian materi pertama seni tari kreasi anak serta penyampaian gerak dasar tari kreasi anak yaitu tari semut. Sesi kedua, hari selasa 9 Mei 2017 pukul 12.3015.00 dimulai penyampaian materi gerak bagian 1 dan 2. Sesi tiga, hari rabu tanggal 10 Mei 2017 pukul 12.30-15.00 penyampaian materi gerak bagian 3. Sesi empat, hari kamis tanggal 11 Mei 2017 pukul 12.30.00-15.00 penyampaian materi gerak bagian 4 dan mengulang atau mengingat kembali materi gerak bagian 1,2, dan 3. Sesi lima, jumat tanggal 12 Mei 2017 pukul 12.3015.00 peserta mempraktekkan materi gerak tari semut yang sudah disampaikan serta membentuk pola lantai sesuai dengan kreatifitas masing-masing siswa.

Evaluasi pelaksaan kegiatan pengabdian kepada masyarakat dilaksanakan dengan perincian sebagai berikut : Kehadiran dan tingkat partisipasi peserta melalui presensi kehadiran adalah $100 \%$. Berdasarkan jadwal pelaksanaan, serta ketepatan waktu pelaksaan, kegiatan pengabdian ini telah terlaksana dengan baik, sesuai yang direncanakan. Pada akhir acara peserta mampu menghasilkan dan mempresentasikan tari semut. Pada umumnya anak-anak selalu menyenangi apa yang pernah dilihatnya. Dari apa yang dilihatnya secara tidak disadari atau tidak dengan spontan menirukan gerak sesuai dengan apa yang pernah dilihatnya (Karyati, 2005: 27)). Koreografi dengan tema kehidupan sehari-hari lebih mudah untuk diaplikasikan pada anak-anak karena anak cenderung meniru kebiasaan yang dilihat (Hidajat, 2003). Sesuai dengan kedua pernyataan tersebut, dari apa yang pernah dilihat dan diamati anak-anak, dapat dijadikan suatu tema. Pada umumnya tematema tari yang sering dipakai oleh anak- anak yaitu tingkah laku binatang. Berikut merupakan dokumentasi gambar dari hasil presentasi siswa SDN Sudimoro 1 yang mengkuti pelatihan tari:

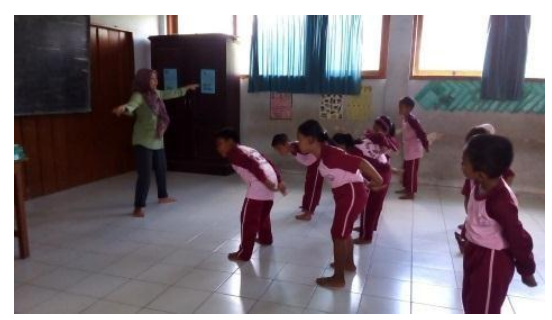

Gambar 5.1 Proses pelatihan tari semut

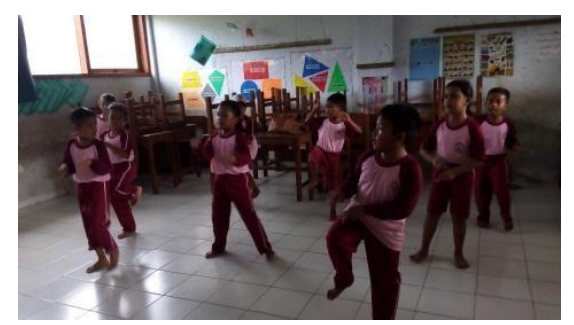

Gambar 5.2 Siswa mempraktekkan gerak tari semut beserta pola lantainya 


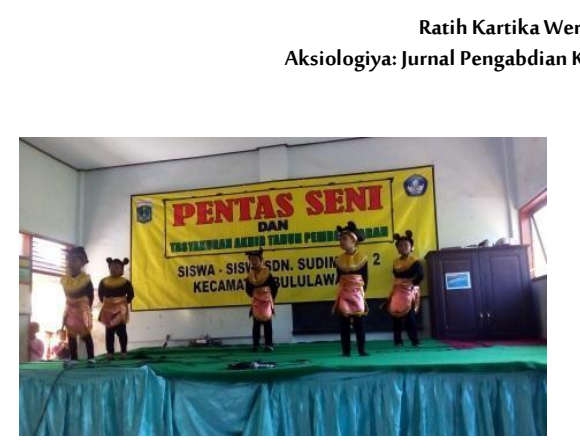

Gambar 5.3 Hasil pelatihan dengan acara pentas seni di SDN Sudimoro 1

Tari semut diperagakan 3 kelompok yang terdiri 7 orang. Tari semut menceritakan tentang kehidupan sehari-hari binatang semut. Yang semula semut berlarian kesana- kemari dan bergotongroyang mencari makan. Dengan riang gembira binatang semut bermain bersama-sama.

Menurut Kamtini dan Tanjung (dalam Dewi, 2009: 27) untuk jenis tari anak, paling tidak memiliki sifat kegembiraan atau kesenangan, geraknya lincah dan sederhana, iringannya pun mudah dipahami. Sependapat dengan Kamtini dan Tanjung, bahwa tari semut yang dilakukan anak SD Negeri Sudimoro 1 Kecamatan Bululawang merupakan tarian anakanak yang ragam geraknya sangat sederhana dan lincah, sehingga ketika peserta didik diajarkan tarian tersebut lebih semangat.

\section{SIMPULAN}

Hasil dari kegiatan pengabdian ini siswa memperoleh banyak pengetahuan dan ilmu mengenai tari kreasi anak, khususnya tari semut. Terutama inovasi dalam pembelajaran seni tari, apa yang telah siswa terima akan diaplikasikan

dalam pembelajaran yang mereka laksanakan. Karena dengan gerak tarian dapat memacu motorik kasar anak.

\section{DAFTAR PUSTAKA}

Hadi, Y. Sumandiyo. 2007. Kajian Tari Teks dan Konteks. FSP ISI Yogyakarta

Hidajat, Robby. 2003. Koreografi Anak. Malang: Balai Kajian Seni dan Desain Fakultas Sastra Universitas Negeri Malang

Hidajat, Robby. 2008. Seni Tari. Malang: Jurusan Seni dan Desain Fakultas Sastra Universitas Negeri Malang

Karyati, Dewi dkk. 2005. Pengantar Bahan Ajar Pendidikan Seni Tari dan Drama.

Bandung: Universitas Pendidikan Indonesia.

Lutan, Rusli. 1986. Pengelolaan Interaksi Belajar Mengajar Intrakurikuler, Kokurikuler, dan Ekstrakurikuler. Jakarta: Karunika Jakarta Universitas Terbuka 